\title{
Ensuring success in a fully online Computer Literacy Module
}

\author{
Niall Dixon ${ }^{1}$ \\ Dublin Institute of Technology (DIT), Dublin, Ireland
}

(Received March 2014; final version received September 2014)

\section{Introduction}

In recent years much has been written about the potential of e-learning to address some of the difficulties that Higher Education Institutions are faced with in relation to reduced academic staffing levels catering to an increasing and diverse student population. The mere mention of e-learning (Hunt, 2011) may indicate an assumption that e-learning will solve these issues. Providing access to these systems without sufficient supports reduces the likelihood that these systems will succeed. This presentation and discussion will focus on the need for supports considered essential in the delivery of fully online courses.

\section{Context}

Dublin Institute of Technology (DIT) has its origins in technical education extending back over 100 years and currently awards up to doctorate level in a wide variety of disciplines including; Business, Arts, Tourism, Engineering, Built Environment, Science \& Health. Basic ICT skills using "productivity" software such as Word Processing, Spreadsheets, Presentation software are deemed essential tools for students (Ezziane, 2007, Gnudi and Lorenzi, 2002). Modules containing these topics are at the core of many undergraduate programmes. The initial stage of this research focussed on the use of the ITA by a group of 71 students studying Auctioneering, Valuations and Estate Agency in the school of Real Estate. The IT module is allocated 2 hours per week and its overall aim is to:
...introduce the student to the uses and applications of information technology. ... develop student proficiency in using a range of computer applications including Microsoft Excel, Word and PowerPoint; and provide an understanding of how students can better organise, manage and implement their studies using IT and apply the practical skills necessary in the production of coursework, projects and presentations. (McCann and O'Shea, 2010)

Learning outcomes were assessed by end-of-semester examinations and progression to the second year of this programme is based on successful completion of these assessments. The designers of this online module were cognisant of the perception (McLennan and Gibbs, 2008) that traditional first year entrants automatically have good productivity software skills due to the transfer of their Internet, Web 2.0 and Social Networking skills. It may also be assumed that second level entrants in general also have good software productivity skills due to the fact that IT subjects are covered in secondary schooling and that students have sufficiently grasped these subjects (Edmiston and McClelland, 2000,

\footnotetext{
${ }^{1}$ Corresponding author. Email: niall.dixon@dit.ie

Irish Journal of Technology Enhanced Learning Ireland, 2014. (C) 2014 N. Dixon. The Irish Journal of Technology Enhanced Learning Ireland is the journal of the Irish Learning Technology Association, an Irish-based professional and scholarly society and membership organisation. (CRO\# 520231) http://www.ilta.ie/. This is an Open Access article distributed under the terms of the Creative Commons Attribution 4.0 International License (http://creativecommons.org/licenses/by/4.0/), allowing third parties to copy and redistribute the material in any medium or format and to remix, transform, and build upon the material for any purpose, even commercially, provided the original work is properly cited and states its license.
} 
Oblinger and Oblinger, 2005). Both these assumptions are dismissed in this study leading to an emphasis on design weighted towards the less IT computer literate learner.

\section{Background}

The option to provide this module in a fully online format came about as a direct result of a reduction in the availability of IT teaching staff at DIT due to financial restraints. The lack of experienced IT lecturing staff has resulted in non IT specialists delivering these essential modules. For the purpose of this study, the author, an IT subject specialist, delivered this module in a fully online mode. At the outset, the role of the online tutor was to deliver a once off face-to-face induction presentation, provide a structure to the course, guide students through a range of topics and provide support via e mail and to provide some face-to-face tuition when required.

\section{Description of the Study}

\subsection{Microsoft ${ }^{\text {IT Academy Program }}$}

The IT Academy is a web based learning system which provides learning resources for the full suite of Microsoft applications. It is hosted and maintained by Microsoft US. Like many commercially available systems it has some limitations. It affords the usual benefits of most LMSs - access anywhere, anytime and at any pace. It was selected as the Learning Management System (LMS) of choice for DIT (specifically for MS applications) due to its low annual subscription cost. Its alignment with the concept of scaffolding is evident in the provision of video demonstrations of tasks and the provision of hands-on exercises where tasks are broken down into chunks. There is an e-mail feature within the system and a discussion forum but these are not activated on the DIT licence agreement. Access is by way of a userid and password. It also has a reasonable reporting function to track student activity and progress.

Gagne's "Events of Instruction" (Gagné, 2005) are evident in the design of the IT Academy. Modules are "chunked" and presented in a variety of modes appealing to different learning styles e.g. video simulations, interactive videos, self tests and practical "lab" exercises. Access is by way of a username, password and access codes. The design of the overall IT module identified a core set of skills within each collection and these were aligned with the specific learning outcomes. Consequently, not all modules and lessons were mandatory. The more advanced students have the opportunity to complete optional lessons.

\subsection{Induction}

On the first day of this module students received an induction onto the module consisting of a detailed presentation and demonstration in the use of the IT Academy. They were asked to log in and navigate through a sample course. It was explained that this is a fully online system and that it would require some degree of self-directed learning, a concept that may appear new to traditional first year entrants or one that may require development. (Nikolova and Collis, 1998) report that "a higher demand on the learner's self-initiative, self-motivation, and self-control" is required to succeed in these type of learning environments. To address this, weekly e-mails were used as an extrinsic motivating factor to engage the students (Biggs and Tang, 2007).

\subsection{A Typical week}

Following the induction week, a typical week for a student could be characterised as follows:

- notification of weekly tasks via e mail i.e. specific modules and lessons

- logging on and completing the required lessons including the hands-on practical exercises 
- $\quad$ sending queries in relation to system usage or lesson content via e-mail to the online tutor

- receiving responses from the tutor usually within 24 hours

- attending group "drop-in" sessions for those who required face to face assistance

- attending one-to-one tuition sessions if required.

\subsection{Module Website}

The website was constructed as a central source of information including modules and required lessons, access codes, links and references. It also incorporated supports to the lessons such as a glossary of terms, an FAQ, and a collection of additional instructions. The FAQ section grew as a result of recurring questions from students. The following is a typical e-mail from a student who had difficulty using the system:

\begin{tabular}{|l|l|}
\hline Question & Answer \\
\hline $\begin{array}{l}\text { Hi,I can get access to the site and have } \\
\text { completed the 1st course. However } \\
\text { when I logged on with the second }\end{array}$ & $\begin{array}{l}\text { I'm logged in but I don't really understand the menus } \\
\text { and what is being asked of me? WELL DONE! You have } \\
\text { access code I don't seem to be in on the } \\
\text { successfully logged in. You need to read all the screens } \\
\begin{array}{l}\text { especially the first one. Make sure you click on the } \\
\text { around the site as I am not given any } \\
\text { exercises to do }\end{array}\end{array} \begin{array}{l}\text { "Navigation Overview" link when you get into a course - it } \\
\text { is a video of how to use the system and runs for about } 2 \\
\text { minutes it is well worth viewing this the first time you log in. }\end{array}$ \\
\hline
\end{tabular}

\section{Data Collection}

A pre-course questionnaire was developed, the focus of which was to evaluate the student's general IT awareness $(\mathrm{n}=71)$. A summary of the results are as follows:

- Male/Female $=78 \% / 22 \%$

- School leavers/other $=54 \% / 46 \%$

- Access to a computer $=100 \%$

- Hours spent on computer per week $=50 \%$ of students spent $5+$ hours

- Studied any IT previously $=89 \%$

Only $16 \%$ of respondents ranked as most important, the use computers for the creation of documents and spreadsheets, whereas $\mathbf{3 6 \%}$ ranked this as their least important use of computers.

The cohort which was the subject of this initial study was made up of varying backgrounds ranging from the typical school leaver to an out-of-work bricklayer. Those students who studied IT prior to college reported that they completed a range of courses from a single MS Word course to a full suite of MS Office products. As the module progressed, e-mails provided a qualitative representation of the experience of students. Most of the e-mails were in relation to the use of the system e.g. forgetting password, unsure of what was being asked, not working in a certain browser, not having the correct software version at home so unable to practice from home and finally, navigating the system.

An unstructured focus group was held prior to the final exam of which the results were: system difficult to use but became used to it after time, too many steps, would like more face-to-face tutorials, enjoys using Excel as a result of module, required MS Paint for other subjects on programme but not part of IT module.

\section{Lessons learned, so far...}


This research is on-going however there are a few recommendations to be made. The first major finding is that the students simply will not succeed if learning supports are not in place to complement and enhance the online learning system. A variety of different approaches being considered that will improve the student experience include; provision of a short pre-programme face-to-face bridging module (Calder, 2000), more face-to-face tutorials to supplement the online learning system for weaker students (Reeves et al., 2002), more frequent tests with specific deadlines to promote better engagement, a more considered relationship with other modules on the programme, some element of localisation of the learning system itself to address ambiguity of interpretation of instruction.

\section{Discussion}

Undoubtedly, e-learning has the potential to alleviate some of the pressures that faculty are faced with today. The use of commercially available learning systems will have minimal impact in isolation if they are not packaged with well designed appropriate supports.

\section{References}

Biggs, J. B. \& Tang, C. 2007. Teaching for quality learning at university, Maidenhead, McGrawHill/Society for Research into Higher Education \& Open University Press.

Calder, A. 2000. Online Learning Support: an Action Research Project. The Fourth Pacific Rim First Year in Higher Education Conference: Creating Futures for a New Millennium. Queensland University of Technology. Brisbane.

Edmiston, E. \& McClelland, M. 2000. A conversation about ensuring computer literacy of first-year students. Proceedings of the second annual CCSC on Computing in Small Colleges Northwestern conference. Oregon Graduate Institute, Beaverton, Oregon, United States: Consortium for Computing Sciences in Colleges.

Ezziane, Z. 2007. Information Technology Literacy: Implications on Teaching and Learning. Journal of Educational Technologyand Society, 10, 175-191.

Gagné, R. M. 2005. Principles of instructional design, Belmont, CA, Thomson/Wadsworth.

Gnudi, A. \& Lorenzi, A. E-Learning to Acquire the Basic ICT Skills for First-Year University Students. In: Wagner, E. \& Szucs, A., eds. European Distance Education Network; Open and distance learning in Europe \& beyond : rethinking international co-operation, Jun 2002 Granada, Spain. Budapest, 551-555.

Hunt, C. 2011. National Strategy for Higher Education to 2030. In: Skills, D. O. E. (ed.). Dublin, Ireland: Government Publications Office.

McCann, P. F. \& O'Shea, C. 2010. DIT Coursewise [Online]. Available: http://modulecatalogue.hosting.heanet.ie/catalogue/modules/RECE1134/ [Accessed 20th September 2010.

McLennan, T. \& Gibbs, S. 2008. Has the computing competence of first year university students increased during the last decade? In Hello! Where are you in the landscape of educational technology? conference. Ascilite. Melbourne, Australia.

Nikolova, I. \& Collis, B. 1998. Flexible learning and design of instruction. British Journal of Educational Technology, 29, 59-72.

Oblinger, D. \& Oblinger, J. 2005. Educating the Net Generation. In: Oblinger, D. \& Oblinger, J. (eds.). EDUCAUSE.

Reeves, T., Baxter, P. \& Jordan, C. 2002. Teaching computing courses - computer literacy, business microcomputer applications, and introduction to programming online utilizing webCT. Journal of Computing in Small Colleges, 18, 290-300. 